\title{
The Effect of Headmaster Certification and Supervision on Teacher Performance at Gunung Jati Elementary School in Cempaka District
}

\author{
Nurjanah $^{1 *}$, Bukman Lian ${ }^{1}$, Alhadi Yan Putra ${ }^{1}$ \\ ${ }^{1}$ Universitas PGRI Palembang, Indonesia \\ "Corresponding author. Email: nurjannahgujat@gmail.com
}

\begin{abstract}
The issue of education in Indonesia that must be prioritized is the quality of education. The quality of education in Indonesia has long been emphasized from various perspectives, particularly in terms of teacher performance. Therefore, government efforts to improve teacher quality are carried out through professional development and improvement programs, one of which is teacher certification. The aim of this study is to evaluate the influence of principal certification and supervision on teacher performance. This study is being conducted in the field of education and focuses on schools, specifically GunungJati elementary school in the Cempaka district. In this analysis, questionnaires, observation, and documentation were used to collect data. Respondents in this study were 36 teachers. The data analysis method used quantitative analysis, using the SPSS 21 application. The results of the data analysis from the questionnaire showed that there was an effect of certification on teacher performance at GunungJati elementary school of Cempaka district. The performance of Cempaka district elementary school teachers is influenced by principal supervision. Certification and supervision have an impact on the output of elementary school teachers in GunungJati, Cempaka district.
\end{abstract}

Keywords: Certification, Supervision, Performance

\section{INTRODUCTION}

The issue of education in Indonesia now that must be prioritized is the quality of education. The quality of education in Indonesia has long been emphasized from various perspectives, especially in terms of teacher efficiency. Therefore, government efforts to improve teacher quality are carried out through professional development and improvement programs, one of which is teacher certification. The job title for a teacher cannot be separated from the administrative requirements, but from how the teacher can provide understanding and understanding to students and encourage them to engage in activities related to individual knowledge. They provide. This is related to the intellectual quality of teachers in carrying out their functions as educators and guides. One of the efforts to improve teacher professionalism is to supervise the principal in monitoring teacher performance, that is, teachers are evaluated by the principal, especially in lesson planning. learning process and learning assessment.

In the humanitarian field, professional teachers work as substitutes for parents, especially to improve students' intellectual abilities. Professional teachers become facilitators to help students turn their potential into developing skills and abilities that benefit humanity.
Meanwhile in the social sector, the function of the teaching profession is to fulfill the mandate of the 1945 Constitution, namely to contribute to the intellectual life of the Indonesian nation. One of the efforts to improve the professional attitude of teachers in schools is through supervision. Supervision is an important activity in teaching practice. Through teacher supervision activities, teachers are guided and assisted to improve teaching and learning activities, and in the end, it will produce and improve the quality of learning.

Supervision is an integral component of the overall educational administration process, with the primary purpose of improving school staff performance practices relevant to the core tasks of education. Meanwhile, Ruhayati, et al [1] supervision is a coaching session conducted by the Principal for teachers who focus on professional development through core technical skills and encouragement for personalities and professional attitudes. Wiyono [2] attempts to describe supervision by connecting the function of general leaders who plan and lead school-related learning activities. Supervision is an attempt to enhance education by providing services and support to teachers both individually and in classes. Education supervision is divided into two parts: managerial supervision and academic supervision [3]. The primary goal of supervision is to enhance teachers' 
professional abilities and the standard of learning through effective teaching.

Certification is achieved through a portfolio assessment of teacher success that involves an evaluation of four competencies: pedagogical competence, technical competence, personality competence, and social competence. During certification, teachers and lecturers are given pedagogical certificates. Certification is formal evidence of recognition of teachers and lecturers as specialists. In other words, certification is the method of determining someone's competency to offer educational services to a specific educational unit after completing a competency test administered by the designated Educational Personnel Training Institute. Certification may also be described as an ability-testing process that aims to expose a person's skill mastery as the foundation for awarding educational certificates.

Performance is a multidimensional construct that includes many factors that influence it. These factors include teacher intrinsic factors (personal / individual) or human resources and extrinsic factors [4].

Basically, the Teacher Certification Program is a government initiative aimed at recruiting professional teachers. The status of teachers as professionals serves to elevate teachers' integrity and their function as agents of learning in order to improve the standard of national education. As a professional, teachers certainly have expertise in their fields.

Competence is the knowledge, skills and abilities or abilities of a person who has become part of himself to color his cognitive, emotional and psychomotor behavior [5].

A portfolio is physical evidence (document) that describes the work experience / achievements obtained in fulfilling professional teaching assignments at certain time intervals. this can also be said to be a record of teacher performance during activities as a teacher. Currently, this portfolio document contains elements of experience, work and achievements during the teacher's role as a learning agent. This portfolio evaluation is carried out by tertiary institutions established by the government in accordance with the Decree of the Minister of National Education number 057/0/2007.

Teacher portfolios usually contain elements such as descriptions of learning philosophy, assignments, programs, products of learning activities, descriptions of the stages of learning assessment for teachers. 'improvement. quality of learning.

Teacher certification [6] There are four aspects that teachers must fulfill in certification, namely academic qualifications, skills, physical and mental health and ability to achieve. In order to achieve national quality education, the certification program seeks to assess teachers' viability in carrying out their duties as skilled educators, enhance learning processes and outcomes, improve teacher health, and increase teacher integrity.
The certification program can be taken by all teachers under the auspices of the Ministry of National Education and the Ministry of Religion, with predetermined conditions. As for the phenomenon that occurs in GunungJati elementary school of Cempaka district, there are still many teachers who allow them without clear reasons while teaching, so that their students are not optimal. in getting the material given.

It is also often observed that some permanent teachers at GunungJati elementary school of Cempaka district do not attend classes during school hours, but become honorary teachers who replace these permanent teachers to provide teaching materials to students. If this is not controlled, the teacher in question will act according to his own wishes and desires, regardless of his duties as an educator. Regarding the phenomena that occur in the implementation of the supervision and certification program activities at GunungJati elementary school of Cempaka district, this will directly or indirectly affect teacher performance in teaching.

For this reason, efforts are needed to implement clear and firm rules in the implementation of supervision activities and certification programs in schools. It is hoped that every teacher will be able to improve their performance, both before and after supervision and certification, so that teachers can carry out their roles and functions as educators. Given the rules that apply in schools, it should also provide solutions to problems in the supervision and certification program of elementary school of Cempaka district. Education is part of an important level of human life. The existence of human education can shape their personality by developing their potential according to the values that exist in society. The values that are implemented are part of a process that is in line with the main goal of education, namely to develop the capacity, knowledge, skills and attitudes of students optimally.

These duties include coaching teachers as a profession, education and training. Education entails the transmission and growth of life principles. Teaching entails pursuing and improving science and technology, while teaching entails developing student-teacher skills in the humanities in schools in order to become second parents. He must be able to attract sympathy to become his student idol. All lessons given must be able to motivate students. The level of education quality is strongly influenced by the quality of the learning process carried out by the teacher, as the teacher provides advice and direct assistance to students in an effort to achieve educational goals.

Teachers must be able to become competent educators, as described in the essential education guidebook, who are experts in charge of preparing and executing the learning process, assessing learning outcomes, providing instruction and study, and conducting community service. Particularly for teachers in higher education. Educators must have the minimum qualifications and credential necessary for their level of 
teaching authority, be physically and mentally healthy, and be capable of achieving national education goals [7]. The professional performance of teachers can be supported by the implementation of supervision or direction by the supervisor.

The problems of the teaching profession in carrying out teaching and learning activities will continue and will continue and will be assisted by the supervision of the principal. The principal wants to support the performance of teachers who consistently improve the implementation of learning in schools.

There is a strong tendency that to improve the quality of teacher professional qualification services that need to be nurtured and restructured is its capacity so that in turn it can be used to direct teacher programs to become professional figures in education. This is inseparable from the supervision and guidance of the supervisor. In carrying out their duties, a supervisor is obliged to assist teachers in providing support who can carry out their duties both as educators and as teachers.

As a professional teacher, he must have special skills and be able to master the complexities of education and teaching with a variety of sciences that must be nurtured and developed through certain educational periods. In carrying out activities or jobs in formal institutions, such as schools, it is necessary to evaluate the work done by the teacher. Performance appraisal is one of the processes carried out by government agencies or companies in evaluating teacher performance skills. This evaluation is intended to see the extent to which the development of teacher quality, from the results of teacher performance evaluation, it can be seen the strengths and weaknesses of the work being evaluated and can provide feedback to the employees concerned. This of course requires a clear and objective performance appraisal system that can be used as a guide in evaluating the correct teacher performance. Because the objective and correct evaluation of teachers will encourage better productivity as a force to produce better performance for educators or teachers. In addition to supervision of professional competencies to improve teacher performance, it is also supported by teacher certification.

The professional quality of the teaching function, as well as respect for the requisite fields of expertise, are important dimensions of a skilled teacher [8]. An educator credential is formal proof of professional status, while teacher certification is the process of recognizing that an individual has the competence to provide educational services in a specific educational unit after passing a competency test organized by a certification body [9]. As a result, teacher certification is a competency evaluation procedure designed to reveal a person's competency mastery as the basis for awarding teacher certificates. Teachers are expected to obtain certification because it increases their skill and commitment in carrying out their responsibilities as educators [10].
The resurrection of an area will be closely related to the emergence of a change process in all its aspects, including education issues. This can be seen from the many reforms undertaken by reformers in the field of education, especially from educators who have direct knowledge. Education is considered by many to be the basis for the improvement and formation of human character, morals. Even in the history of human civilization, the intelligence of civilization has always been associated with the education system that supports it. Great civilization is always supported by an excellent education system. This can be seen in the history of Greek, Roman and Islamic civilizations. School as a formal dance education institution deserves to be studied, because there are many aspects related to it. This is the reason why the author conducted research on "The Effect of Headmaster Certification and Supervision on Teacher Performance at Gunung Jati Elementary School in Cempaka District”.

\section{METHODS}

The research was conducted at the GunungJati District Elementary School. The authors used quantitative data in this analysis, which is research that requires the use of numbers from data collection to data interpretation and the presentation of the findings. Quantitative research is a form of research in which the requirements are systematic, designed, and clearly structured from the beginning of the research design to the end.

Population is a generalization field consisting of items / subjects with specific qualities and characteristics that the researcher determines for analysis and then draws conclusions from [11]. This study's participants were all involved teachers at GunungJati elementary school in the Cempaka district, a total of 36 teachers. Samples are some of the items under investigation; they are assumed to be reflective of the entire population and are obtained using particular techniques. For this study, the research samples were the principal as the supervisor as the resource person and the teachers who were active in the school. According to this viewpoint, the authors used the census sampling technique or complete sampling, where total sampling was a sampling technique in which all members of the population, including 36 teachers, were used as samples [11]. Data collection techniques used include observation, questionnaire, and documentation. The hypothesis testing by using correlation techniques, while the correlation techniques used are statistical analysis of correlation and determination, regression coefficient ( $\mathrm{t}$ test) and association correlation coefficient (F test), which were carried out using SPSS version 21. 


\section{RESULTS AND DISCUSSION}

1) Testing the Certification Hypothesis (X1) on Performance (Y)
The design of the impact of school culture and teacher output is expressed in the form of the $\mathrm{Y}$ regression equation $\mathrm{Y}=24.247+0.746 \mathrm{X}_{1}$. The Linear Regression Significance Level can be seen in the table below.

\begin{tabular}{|c|c|c|c|c|c|c|}
\hline \multirow{3}{*}{\multicolumn{2}{|c|}{ Model }} & $\begin{array}{r}\text { Signifi } \\
\text { o }\end{array}$ & $\begin{array}{l}\text { ance of } \\
\text { Perfor }\end{array}$ & $\begin{array}{l}\text { Certification } \mathbf{H} \\
\text { nance }(\mathbf{Y})\end{array}$ & poth & $\mathbf{S}\left(\mathbf{X}_{1}\right)$ \\
\hline & & \multicolumn{2}{|c|}{$\begin{array}{l}\text { Unstandardized } \\
\text { Coefficients }\end{array}$} & \multirow{2}{*}{$\begin{array}{l}\text { Standardized } \\
\text { Coefficients } \\
\text { Beta }\end{array}$} & \multirow[t]{2}{*}{$\mathrm{t}$} & \multirow[t]{2}{*}{ Sig. } \\
\hline & & B & $\begin{array}{l}\text { Std. } \\
\text { Error }\end{array}$ & & & \\
\hline \multirow[t]{2}{*}{1} & (Constant) & 11.025 & 9.336 & & 1.181 & 0.246 \\
\hline & Certification & 0.678 & 0.113 & 0.716 & 5.985 & 0.000 \\
\hline
\end{tabular}

a. Dependent Variable: Teacher Performance

From the table above, the $t$ value is 5,985 with a sig level of 0,000 . Because the sig value is less than 0.05 , the hypothesis that there is an effect of certification on teacher performance at GunungJati Elementary School, Cempaka District is accepted. This means that certification has an effect on the performance of teachers at GunungJati Elementary School, Cempaka District.

\section{2) Supervision Hypothesis Testing (X2) on Performance (Y).}

The organizational commitment relationship model for teacher performance presented in the form of the dependent variable $\mathrm{Y}=49,000+0.379 \mathrm{X}_{2}$. The regression equation significance test can be presented in the table below.

Table 2. Significance of Supervision Hypothesis Testing $\left(X_{2}\right)$ on Performance (Y).

\begin{tabular}{lcccccc}
\hline \multicolumn{1}{c}{ Model } & \multicolumn{2}{c}{$\begin{array}{c}\text { Unstandardized } \\
\text { Coefficients } \\
\text { Std. }\end{array}$} & $\begin{array}{c}\text { Standardized } \\
\text { Coefficients }\end{array}$ & & \\
\hline 1 & B Constant) & Error & Beta & t & Sig. \\
\hline \multicolumn{2}{c}{ Supervision } & 0.768 & 7.384 & & 1.188 & 0.243 \\
\hline
\end{tabular}

a. Dependent Variable: Teacher Performance

From the table above, the $\mathrm{t}$ value is 7,876 with a sig level of 0,000 . Because the sig value is less than 0.05 , the hypothesis which says there is an effect of school principal supervision on the performance of teachers at GunungJati Elementary School, Cempaka District is accepted. This means that the Supervision of the Principal has an effect on the performance of the teachers at GunungJati Elementary School, Cempaka District.

\section{3) Testing Hypotheses of Certification $\left(X_{1}\right)$ and Supervision $\left(\mathrm{X}_{2}\right)$ of Performance (Y)}

The model of the relationship between school culture and the organizational commitment to teacher performance presented in the form of the linear regression $\mathrm{Y}=22.368+0.571 \mathrm{X}_{1}+0.157 \mathrm{X}_{2}$, which means that the performance of teachers will increase positively with the school culture and the organizational commitment.

Table 3. The results of multiple regression analysis of Certification $\left(\mathrm{X}_{1}\right)$ and Supervision $\left(\mathrm{X}_{2}\right)$ of Performance

\begin{tabular}{|c|c|c|c|c|c|}
\hline \multicolumn{6}{|c|}{ (Y) } \\
\hline Model & $\begin{array}{l}\text { Sum of } \\
\text { Squares }\end{array}$ & $\mathrm{df}$ & $\begin{array}{c}\text { Mean } \\
\text { Square }\end{array}$ & $\mathrm{F}$ & Sig. \\
\hline Regression & 498.585 & 2 & 249.292 & 30.128 & $.000^{\mathrm{b}}$ \\
\hline Residual & 273.054 & 33 & 8.274 & & \\
\hline Total & 771.639 & 35 & & & \\
\hline
\end{tabular}

a. Dependent Variable: Teacher Performance

b. Predictors: (Constant), Certification, Supervision 
According to the table above, the $\mathrm{F}$ value is 30,128 with a sig level of zero. The hypothesis that there is an impact of school principal certification and supervision on teacher success at Gunung Jati Elementary School in Cempaka District is acknowledged because the sig value is less than 0.05. This means that the certification and supervision of school principals has an impact on the success of teachers at Gunung Jati Elementary School in the Cempaka District.

\section{CONCLUSION}

Based on previous studies and discussion, either by descriptive statistical analysis or inferential statistical analysis, the findings in this study can be summarized as follows: There is an impact of certification on teacher success at GunungJati Elementary School in Cempaka District, Indonesia. The principal's supervision has an impact on the performance of the teachers at GunungJati Elementary School in Cempaka District. The qualification and supervision of the principal have an impact on the success of teachers at GunungJati District Elementary School Cempaka.

For researchers to follow up further the results of this study by developing independent variables that can improve the performance of the GunungJati State Elementary School, Cempaka District. This needs to be done because there are still other factors that have an influence on teacher performance besides the certification and supervision of the principal because only $81.6 \%$ of the teacher's performance is determined by the Principal's Certification and Supervision, meaning $18.4 \%$ is determined by factors outside of the Principal's Certification and Supervision such as compensation, job satisfaction and others.

\section{ACKNOWLEDGMENT}

Our deepest gratitude goes to Chancellor of Palembang PGRI University, Director of the Postgraduate Program of PGRI Palembang University and the Education Management Study Program of PGRI Palembang University, who have supported us in doing this extraordinary thing. This project is funded independently. We also want to thank our Education Management friends who helped us a lot in a short time frame to complete this project.

\section{REFERENCES}

[1] Ruhayati, Y. (2017). Kontribusi Layanan Supervisi, Kepemimpinan Kepala Sekolah dan Fasilitas Pembelajaran terhadap Kinerja Guru Pendidikan Jasmani SMPN se-Kota Cimahi [Contribution of Supervision Services, Principal Leadership and Learning Facilities to the Performance of Junior High School Physical Education Teachers in Cimahi City]. Jurnal Penelitian Vol.10 No.2.
[2] Wiyono. (2019). Administrasi dan Supervisi Pendidikan [Education Administration and Supervision]. Jakarta: Dirjen Dikti: Depdikbud D2 LPTK.

[3] Kristiawan, dkk. (2019). Supervisi Pendidikan [Education Supervision]. Bandung: Alfabeta.

[4] Yamin, M. \& Maisah. (2009). Sertifikasi Profesi Keguruan di Indonesia [Teacher Professional Certification in Indonesia]. Jakarta: Gaung Persada Press.

[5] Ashan, M. (2005). Competences and Motivation. Terj. Anas S. Baginbo \& M. Ridwan. Jakarta: RinekaCipta.

[6] Komara, E. (2007). 7 Kompetensi Guru Menyenangkan dan Profesional [7 Fun and Professional Teacher Competencies]. Jogjakarta: Power Books IHDINA.

[7] Abas. (2013). Penyelenggara Pendidikan Profesi Guru [Teacher Professional Education Organizers]. Jogjakarta: DIVA Pres.

[8] Fattah, N. (2004). Konsep Manajemen Berbasis Sekolah MBS dan Dewan Sekolah [SBM School Based Management Concept and School Board]. Bandung: Pustaka Bani Quraisy.

[9] Mulyasa. (2012). Kepala Sekolah Profesional [Principal of Professional School]. Bandung: Remaja Rosda karya.

[10] Sagala, S. (2009). Konsep Dan Makna Pembelajaran [Concept and Meaning of Learning]. Bandung: Alfabeta.

[11] Sugiyono. (2010). Metode penelitian Administrasi [Administrative research methods]. Bandung: Alfabeta. 